\title{
Reflections about Tourism as a Total Social Fact
}

\author{
José A Mansilla*
}

Observatory of Anthropology of Urban Conflict (OACU), Spain

Submission: September 17, 2018; Published: September 26, 2018

*Corresponding author: José A Mansilla, PhD in Social Anthropologu, Observatory of Anthropology of Urban Conflict (OACU), 08005 Barcelona, Spain, Email: joseamansilla@hotmail.com

Keywords: Total social act; Sociology; Community; Embedded; Markets; Festival; Toruism; Economy; Phenomenon

\section{Opinion}

Tourism is a highly complex phenomenon. As a productive activity encompasses a huge number of stakeholders and processes: customers and/or tourists, companies and businessmen, workers, intermediaries, laws and regulations, technology, territory, resources, etc. All of them constitute a network, sometimes highly diffused, that has become, currently, one of the main industries worldwide.

From their beginning, human sciences have been interested in social processes, trying to link apparently individual acts with those regularities or patterns that underlie behaviors and relationships established among people. Thus, human social life is full of total social facts, that is, those that "express, at the same time and at once, all kinds of institutions: religious, legal, moral -in these both policies and family- and economic, which adopt special forms of production and consumption, or better provision and distribution, and to which we must add the aesthetic phenomena to which these events give rise, as well as the morphological phenomena that these institutions produce" [1]. In this way, tourism, as a collective human action, could be considered as a total social fact, and this consideration lead us to try to understand its holistic nature. Let see a couple of examples.

When an old and traditional market in the center of any city becomes a tourist attraction, we do not only have to observe and analyze the consequences that this action has for the balance of payments of local companies or the number of people that visit the emplacement, but we need also take into account the effects on the patterns of consumption of the social fabric of the area this new activity develops; the aesthetic changes that are generated, often directed mainly at the tourists; the regulatory modifications to which, sometimes (Figure 1), competent administrations introduce; the new possible political struggles among parties or/ and social movements; the displacement of families, when they see their daily normality altered or an initial process of gentrification stars, and many other variables.

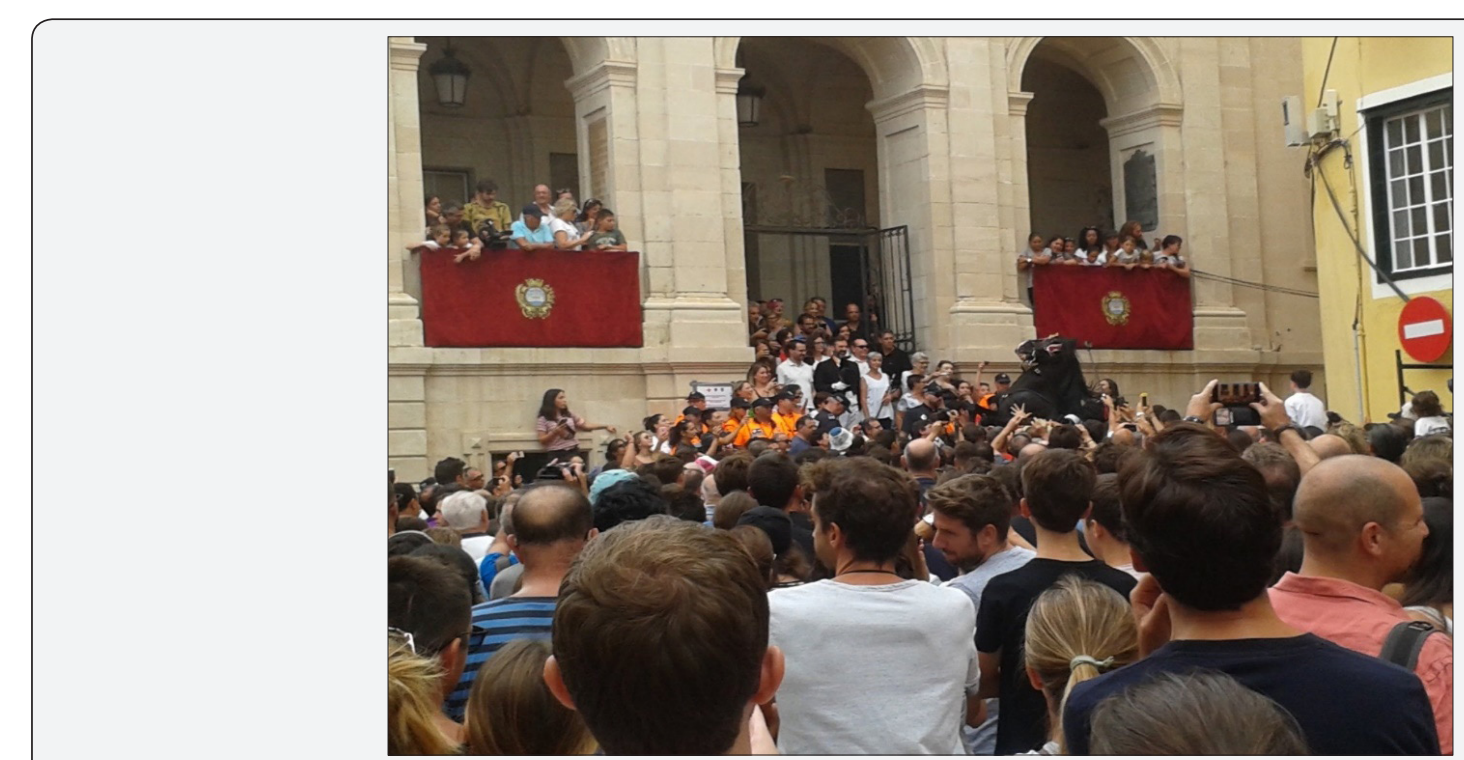

Figure 1: Reflections about Tourism as a Total Social Fact. 
Or, when a popular festival begins to appear in the brochures for tourist promotion agencies and escapes from the hands of its traditional target audience: the local community. In this case, we have not only to value the event as a resource of the so-called underutilized, but also the role that the festival plays in the traditional dynamics of renewal of local identity, the modification of individual and collective religious practices, the renewals of social solidarity, etc.

In short, tourism is a phenomenon that is not produced in an empty space and time. It is embedded in a wide range of institutions and social practices that, like a gigantic mechanic, sees its structure altered, its actions and human relationships modified. This does not have to be initially negative or positive, changes are inherent to all the societies and we are witnesses of this just by looking back. But any transformation has its consequences and that is something we should never forget.

\section{References}

1. Mauss M (2013) Sociologie et anthropologie. Presses Universitaires de France, Paris, France.

\section{Your next submission with Juniper Publishers will reach you the below assets}

- Quality Editorial service

- Swift Peer Review

- Reprints availability

- E-prints Service

- Manuscript Podcast for convenient understanding

- Global attainment for your research

- Manuscript accessibility in different formats

( Pdf, E-pub, Full Text, Audio)

- Unceasing customer service

Track the below URL for one-step submission https://juniperpublishers.com/online-submission.php 